\title{
Fall From Grace Or Glass Ceiling
}

Sambhavi Lakshminarayanan, Medgar Evers College - City University of New York, USA

\begin{abstract}
Wall Street has had few women in top leadership positions. Zoe Cruz was one of the highest ranking women in the financial services industry. She spent her career working at one firm where she rose to the rank of Co-President. However, soon after reaching the highest levels, Zoe Cruz abruptly left the firm after twenty-five years of service. Ms. Cruz's departure proved controversial and commentators had a range of opinions. There were at least three broad interpretations of the situation: one, that she had a moral obligation to leave; two, that organizational politics had forced her out; and, three, that many of the problems she faced could be traced to the fact that she was a woman working in a domain and culture dominated by men.
\end{abstract}

The case is aimed at identifying factors and forces that were at work in the situation. It also poses the question of deciding whether gender and culture related factors were at work against Ms. Cruz's interests or whether what happened was post-gender and simply par for the course.

Keywords: Gender; Women; Leadership; Financial Services; Ethics; Career

\section{INTRODUCTION}

e n 2006, Forbes listed Zoe Cruz at number 10 among the 100 most powerful women (Zoe Cruz Listed \# 10, 2006). By the beginning of 2007, Zoe Cruz was listed among the 25 highest paid women in business by Fortune magazine (25 Highest Paid Women, 2007); she had just taken home a pay check of $\$ 30$ million as Co-President of Morgan Stanley. On December 1, 2007, Zoe Cruz left Morgan Stanley; it was her last day on the job.

In an official press release in November 2007, Morgan Stanley reported Zoe Cruz's leaving the firm as a "retirement" after twenty-five years of service (Huliq, 2007). Many had reason to doubt this announcement. There were questions whether this was, in reality, a case of voluntary departure or a forced one. In particular, speculation was rife that it was the latter since Ms. Cruz had shown no indications of wanting to leave. She had worked at the firm since her graduation with an MBA from the Harvard Business School and seemed to be on the fast track to the very top. As late as November 2007, an article in the New York Times reported that she was a front-runner in the succession planning of Morgan Stanley CEO John Mack (Thomas, 2007a).

What had brought about this dramatic turn of events? Why had a high flying Wall Street career apparently crashed? One possible reason was the turmoil in the financial services industry at that time that had been caused by trading in mortgages and which continued on even after Ms. Cruz's departure. Another important reason was the internal politics of the firm and the role that Ms. Cruz played in it.

Morgan Stanley was founded in 1935 (Morgan Stanley) and was a stalwart of the financial services industry. Worldwide employment in the company was upwards of 50,000 people in 2006 (Fortune Global 500: Morgan Stanley, 2006). The company headquarters was located in New York City. Morgan Stanley merged with Dean Witter, Discover \& Company in 1997 in an attempt to diversify within the financial services sector. The Discover unit was subsequently divested in 2006. The firm's products, as stated in the company website (www.morganstanley.com) include institutional investments as well as wealth management for individual investors. The Fixed Income group, that Zoe Cruz later headed, was one of the divisions of the firm. 
Zoe Cruz had joined Morgan Stanley, recruited in 1982 right out of business school, to work at the foreign exchange desk. She soon moved on to trading foreign currency. These were reportedly conscious and deliberate career choices on her part, although the trading area, in general, is well-known to be dominated by men. The choice of being on the trading floor is of no little importance in Ms. Cruz's career growth; it set the stage both for her rise through the firm, as well as development of certain personality traits. As reported in New York Magazine (Hagan, 2008), Ms. Cruz felt she needed to be "more alpha than most women" and at least as aggressive as the men on the trading floor to survive and succeed in this arena. Although married and having three children, Ms. Cruz was nonetheless dedicated to her career, putting in the long hours that were common for those working in that area. The New York Magazine article mentioned that even as she went into labor, she continued to take calls about certain trades related to her work.

By 1990, Zoe Cruz had become a Managing Director. By 1997, she had risen to be head of the fixed income division. She was within striking distance of the highest offices in the firm, particularly as the division she headed began to bring in more percentage of revenue for the firm. Through her career until then, an associate and possible supporter of hers was John Mack.

Two important events occurred in the years following her rapid rise that had great impact on her future at Morgan Stanley. The first was a well-publicized move in early 2005 by several executives and board members who disagreed with the direction that CEO Phillip Purcell was taking the firm. This group was vocal in stating their opinion that he needed to be replaced (Thomas, 2005). As reported later in New York Magazine, Ms. Cruz supported Mr. Purcell at that juncture, in contrast to many top executives of the firm. Ms. Cruz was made the CoPresident and member of the Board of Directors by Mr. Purcell later that year. However, Mr. Purcell left the firm shortly thereafter and was replaced by John Mack. Some of Mr. Purcell's critics left the firm as well, although many remained.

The second train of momentous events happened with regard to the division Ms. Cruz headed and the work they were doing. After Ms. Cruz took over, her division's revenue increased by $65 \%$ in 2003. By 2004, its contribution was $\$ 5.6$ billion and it accounted for $14 \%$ of the firm's total income (Hagan, 2008). In line with other (competing) firms, Ms. Cruz's division aimed even higher and began trading in mortgages, both subprime and highquality (in 2006). Around that time, the mortgage unit was about $15 \%$ of her area's balance sheet. As is common knowledge, decisions to trade in these risky securities ultimately backfired. The decimation and demise of old and venerable firms like Bear Sterns and Lehman Brothers was attributed to financial strategies related to mortgages.

For Zoe Cruz's division, alarm bells about the trading strategies began sounding in May 2007 and by August 2007, the losses had already reached $\$ 1.5$ billion. Although the firm tried to extricate itself from the situation, the losses continued to accumulate. Reportedly, Ms. Cruz admitted the losses were heavy, but that they were not the worst when compared to their peer firms (Hagan, 2008).

Despite steep losses due to mortgage-backed securities in mid-2007, Ms. Cruz continued as co-President of the firm. Then came the sudden and unexpected press release in November 2007 announcing her departure. As a matter of note, the final amount reported by Morgan Stanley was losses of $\$ 3.7$ billion on these securities (Rothworth, 2007).

In the aftermath of these events, several commentators proposed different viewpoints. Some suggested that it would have been acceptable and appropriate for the firm to have asked Zoe Cruz to leave and she should, in fact, have taken responsibility for the losses and volunteered to leave (How Zoe Cruz Lost, 2007, Zoe Cruz's Departure, 2007). This viewpoint stated that these losses had happened in her division, under her watch and thus were her ultimate responsibility, and was critical of reports that Ms. Cruz had laid blame at the feet of her subordinates and colleagues - Howie Hubler (a trader in mortgages, Neal Shear (Howie Hubler's boss) and Tom Daula (the firm's risk manager).

An article in New York Magazine (Hagan, 2008) took a different view. The article detailed Zoe Cruz's life and career, and presented her as a driven and hard-working individual who was also very results focused. This viewpoint interpreted the situation as yet another proof that the glass ceiling was very much present for women in 
Wall Street. Implied was the conclusion that Ms. Cruz had paid for the price for being a highly successful woman in a male-dominated arena.

A third viewpoint suggested that it was Ms. Cruz's apparently abrasive persona and lack of political skills that was to blame. An article in New York Times (Thomas, 2007b) refers to her "polarizing" demeanor. This viewpoint implied that she had antagonized key people in the firm, yet made no secret of her ambition to ascend to the highest post. Despite her talents and unquestionable abilities, it was reported hostility on the part of fellow executives and other employees that led to her downfall.

How could everything have unraveled so suddenly? Were the losses in 2007 the turning point that shot down a brilliant and possibly ground breaking career that would have put in place the first woman CEO of a major Wall Street firm? Was this the usual turmoil and churning among high risk takers in the financial industry (Rothworth, 2007) or was this an instance of the glass ceiling (Hagan, 2008)? These questions were asked all around Wall Street as the future of women executives ascending to the highest levels of power came into play once again.

\section{AUTHOR INFORMATION}

Sambhavi Lakshminarayanan is a faculty member in the School of Business, at Medgar Evers College, City University of New York. She teaches courses in business and management, including operations management and business strategy. Her research interests are wide-ranging. After obtaining a PhD in Management Science, she began conducting research in quantitative modeling and integer programming. Subsequently, she also worked on issues ranging from that of managing diversity to developing teaching methods for non-traditional business students. She has also written business cases and books on management. E-mail: sLakshminarayanan@ mec.cuny.edu

\section{REFERENCES}

1. Fortune Global 500: Morgan Stanley. (2006). Fortune. Retrieved July 14, 2009 from http://money.cnn.com/magazines/fortune/global500/2006/snapshots/905.html.

2. Hagan, J. (2008). Only the Men Survive: The Crash of Zoe Cruz. New York. Retrieved July 13, 2009 from http://nymag.com/news/business/46476.

3. Huliq (2007). Zoe Cruz Retires From Morgan Stanley. Retrieved July 13, 2009 from http://www.huliq.com/43521/zoe-cruz-retires-morgan-stanley accessed July 13. Also available on Morgan Stanley website under press releases.

4. Morgan Stanley. Retrieved July 14, 2009 from http://www.morganstanley.com/about/company/history.html.

5. Rothworth, C. (2007). Morgan Stanley's Zoe Cruz Steps Down. International Business Times, 29/November/2007. Retrieved July 13, 2009 from http://www.ibtimes.com/articles/20071129/morganstanley-zoe-cruz-steps-down-john-mack.htm.

6. Thomas, L. Jr. (2005, April 6). Morgan Dissidents Offer Replacement for Purcell. The New York Times. Retrieved July 13 from http://www.nytimes.com.

7. Thomas, L. Jr. (2007a, November 9). At Morgan Stanley Executive, A New Focus on Succession. The New York Times. Retrieved July 13, 2009 from http://www.nytimes.com.

8. Thomas, L. Jr. (2007b, November 30). Morgan Stanley Executive Ousted After Trading Loss. The New York Times. Retrieved July 13, 2009 from http://www.nytimes.com

9. 25 Highest Paid Women. (2007). Fortune. Retrieved July 14, 2009 from http://money.cnn.com/galleries/2007/fortune/0709/gallery.women_highest_pay.fortune/.

10. How Zoe Cruz Lost Her Job on Wall Street. (2007, December 1). Wall Street Journal. Retrieved July 13, 2009 from http://online.wsj.com.

11. Zoe Cruz's Departure from Morgan Stanley. (2007, December 2). Hoovers Business. Retrieved July 13, 2009 from http://www/hooversbiz.com/2007/12/02/zoe-cruzs-departure-from-morgan-stanley.

12. Zoe Cruz Listed \#10 in 100 Most Powerful Women. (2006). Forbes. Retrieved July 14, 2009 from http://forbes.com/lists/2006/11/06women_Zoe_Cruz_V9JO.html. 


\title{
TEACHING NOTES \\ Fall From Grace Or Glass-Ceiling
}

\begin{abstract}
Wall Street has had few women in top leadership positions. Zoe Cruz was one of the highest ranking women in the financial services industry. She spent her career working at one firm where she rose to the rank of Co-President. However, soon thereafter, Zoe Cruz abruptly left the firm after twenty-five years of service. Many explanations abounded - some attributing it to gender-related factors and others to a general trend sweeping the industry in traumatic times.
\end{abstract}

\section{SYNOPSIS}

This case traces the events that led to the downfall of Zoe Cruz. Ms. Cruz had a fast rising career through the only firm she worked at, Morgan Stanley. Having joined the firm's trading department in 1982, she was a co-President of the entire firm and had broad purview of the fixed income areas by 2006. In 2007, she was listed among the 25 highest earning women executives by Fortune, having taken home $\$ 30$ million in 2006. However, Zoe Cruz faced two major challenges during critical points in her career. In 2005, several top executives banded together to urge the ouster of then CEO Philip Purcell. Zoe Cruz broke ranks with them to support him and was subsequently made coPresident. However, CEO Purcell was replaced with John Mack as CEO that same year. John Mack was an old coworker and, some say, mentor of Ms. Cruz. Having shown rapid growth of her area of responsibility in the firm, Ms. Cruz was given broader responsibility and retained the position of President. In the beginning Ms. Cruz's division performed very well, showing healthy growth in revenues. But soon the cracks began to show as the subprime mortgage market debacle began. The losses mounted for her division and finally reached more than $\$ 3$ billion by the end of 2007. In December 2007, Ms. Cruz reportedly retired from the firm.

Ms. Cruz's departure was controversial. There were at least three interpretations of the situation:

1. she was morally obligated to leave, and should have gracefully left after taking responsibility instead of pointing fingers at others.

2. she was generally disliked and several employees reportedly did not want to work for her, further alleging that she had not taken care to understand her division's work thoroughly and so underestimated the risk.

3. she was unfairly blamed and paid the price for being a woman. Many of the factors that led to her being disliked (such as her tough manner) were necessary for her to succeed in a male-dominated workplace. Subordinates did not respect her mainly because she was a woman. They ignored her direct orders and that ultimately led to her downfall.

The case poses the dilemma of whether what happened to Ms. Cruz was par for the course, or whether gender and culture related factors were at work.

\section{LEARNING OBJECTIVES}

After reading and analyzing this case, students should be able to:

1 analyze the stages of career growth in an organization

2 analyze and identify characteristics of the personality of the main protagonist

3 identify general characteristics of a successful executive within an organization

$4 \quad$ list ethical considerations and philosophies of executive actions

5 analyze a political situation in a workplace, list possible actions and their consequences 


\section{TARGET AUDIENCE AND USE OF CASE}

This case is mainly intended for use in courses in Organizational Behavior, Women in Business or Career Development. It can also be used in introductory management or ethics courses. Discussion could be about managing careers in an organization, strategies and tactics that women to survive and succeed (particularly in a male-dominated workplace), organizational politics and ethically influenced actions. Since this is a short case, it could be used for in-class discussions or even assigned for written analysis. During in-class discussions, students can also be asked to role play - with female or male students taking on the role of Zoe Cruz and also other individuals in the firm.

\section{SUGGESTED QUESTIONS}

1. What strategies did Zoe Cruz in her workplace to get ahead?

2. What was the perception of Zoe Cruz? Was it influenced by her being a woman?

3. Identify the personality traits of Zoe Cruz.

4. Would you say that Zoe Cruz was powerful at the firm? What were sources of her power?

5. Was Zoe Cruz morally responsible for the losses of her division?

6. What would you have done if you were in Zoe Cruz's situation when the losses started mounting?

7. How would you explain Zoe Cruz's actions in terms of attribution and ethics?

8. Trace the organizational politics at work in the firm that affected Ms. Cruz's career. Do you agree with her approach in dealing with them?

9. Could, and should, Zoe Cruz have done anything to salvage the situation of the financial losses?

\section{SUGGESTED ANSWERS}

1. What strategies did Zoe Cruz in her workplace to get ahead?

This is a subjective interpretation based on case information.

a. Learned to be tough to survive in an aggressive environment

b. Worked very hard and showed dedication to job (worked through labor, put in 16 hour days)

c. Focused on proving herself through results and not by camaraderie.

d. Chose challenging and high profile jobs that had high risk but also opportunity for high financial return and career growth

2. What was the perception of Zoe Cruz? Was it influenced by her being a woman?

It is likely that people's (fellow employees and higher management) perception of Zoe Cruz was influence by her being a woman. Many of the perception characteristics, with an attached negative connotation, have been said of other women in high positions. For instance, that although Ms. Cruz was reported as tough, one view suggested that she was incompetent (and that she did not understand her division's work). A similar charge had been leveled at Carly Fiorina when she was CEO of Hewlett-Packard, where she was held liable for "faulty execution of strategy".

Perceptions play a critical role, particularly as employees rise up in an organization and into leadership positions. In this regard, we may note that, according to Yukl (2006), discrimination against women is common, especially as leaders and in the corporate world. Yukl comments that just $3 \%$ of top executives are women and that this can be attributed to the persistent belief (in the past) that men were better leaders. This belief was based on:

a. Implicit theories: certain traits and skills are required for effective leadership. These traits include being: confident, task-oriented, competitive, objective, decisive and assertive.

b. Gender Stereotyping: women and men are different, and women both do not have or do not want to behave like (male) leaders.

c. Role expectations: ideas about how women should behave. 
Thus, even if women did show the masculine traits as they stepped into leadership positions, they were not accepted as true leaders.

There is some indication that ideas about women leaders and leadership in general, are changing now, with "feminine" traits such as interpersonal skills, and building cooperative relationships being accepted as leadership qualities also. However, this is likely to be a slow and gradual change, as evidenced by the disparity between numbers of women at different levels of business organizations. It is possible that Zoe Cruz was caught in the "leadership trap" although she did show a lot of the "masculine" traits.

Zoe Cruz's choice and natural inclination to enter spheres typically dominated by men, and deliberate choosing of how to function there went a long way to build a certain "persona" about her. This persona was at odds with commonly accepted feminine characteristics - such as agreeableness and a "lets get along" attitude. Some of the characteristics of this persona were:

a. She was tough and hard working

b. She was capable, even expert, at her job (in an area of specialization)

c. She was not warm or friendly, and not specially supportive of women

d. She did not (know how to) make friends

e. She was not loyal to her peers as a top executive (she looked out for number one)

However, it appears that these characterizations did not work in her favor as she went up the career ladder.

3. Identify the personality traits of Zoe Cruz.

Personality is defined as a stable set of characteristics that influences an individual's behavior. There are several theories to explain differences in personality, such as the Traits theory, Psychodynamic Theory, Humanism and the Integrative approach. (Nelson and Quick, 2008)

The "Big Five" traits theory identifies traits such as - extraversion, agreeableness, conscientiousness, emotional stability and openness to experiences.

Some personality characteristics that influence an individual's behavior in an organization are listed below:

a. Locus of control: general belief about internal (self) versus external (organizational) control over situations

b. Self efficacy: general belief that one can meet job demands in a variety of situations

c. Self esteem: general feeling of self-worth

d. Self monitoring: extent to which a person modifies behavior on cues from others and situation - low self monitoring implies the same behavior in all situations

Descriptions of Zoe Cruz's personality have identified her to be highly competitive, outgoing, aggressive, and focused on outcomes. In terms of the theories, this translates to Ms. Cruz being extraverted (Big Five) and being open to experiences (in her taking up new assignments, where there were few women before her). She appeared to have strong sense of internal locus of control, this is shown by her taking up challenging jobs in the firm. This is in tune with the general experience that people with this characteristic typically rise to higher ranks of management. She also appeared to have a high sense of self-efficacy, as shown in her independent handling of the mortgage decisions. On the other hand, she does not appear to have changed her professional behavior much, either in her response to the executive and shareholder revolt or in her waiting out the mortgage crisis, which points to her low self-monitoring.

4. Would you say that Zoe Cruz was powerful at the firm? What were sources of her power?

Power is defined as the ability to influence others. There are several bases for power in organizations, chief among them: reward, coercive, legitimate, referent and expert (Nelson and Quick, 2008). The last two have been linked to organizational effectiveness, whereas the first three are the most commonly used, but least effective. These power bases are not independent of each other and change for an individual as he or she 
progresses through the organization. Power is not static or strictly increasing along time. An individual may lose or gain power, while continuing in the same position or moving positions, during his or her tenure in an organization (Yukl, 2006). For example, power can come from influence on and support of a group. Such power is often linked to group loyalty as well as competence; success leads to increase in this power and failure to decrease.

Zoe Cruz became very powerful at the firm, she was one of the top most executives. By being in that position, she had legitimate or positional power. In her rise to the top, she had obtained other kinds of power. These are associated with legitimate power - reward and coercive (as in the ability to get an employee fired). We can infer that Ms. Cruz also had a degree of expert power, given the areas she worked in.

However, in all the reporting about Ms. Cruz, there are no comments about her referent power. On the other hand, there is mention of John Mack's persuasive abilities and charisma. From this we can infer that most of her power came from position and competence rather than personality.

5. Was Zoe Cruz morally responsible for the losses of her division?

In any firm there is a sense of employee responsibility and accountability. Depending on the organization, this is implicit and driven by employee behaviors or explicit and stated as a requirement. In this case, depending on which version we read, the responsibility for the losses can be either laid solely at Zoe Cruz's feet, is the total shared responsibility of a number of people (including the CEO) or a system-wide effect that spanned the entire industry, if not the economy. In the latter two interpretations, Ms. Cruz gets a smaller share of the "blame". As stated there were multiple views of the situation. One view stated that Ms. Cruz should be held responsible, since she did not read the situation right and indeed did not understand the true magnitude of what her division was doing. The second view was that she understood, at least well enough when the losses grew, but was not strong enough to stop them. Further, that she was also not strong enough to accept blame stoically (unlike Charles Prince of Citigroup or Stan O'Neal of Merrill Lynch), instead trying to push blame on others. In this view, she had doubly erred in ethical terms. The third view stated that she did understand and try to stop the trading, but was willfully and blatantly disregarded by (male) subordinates who simply did not respect her, mainly on the basis of her being a woman. Moreover, the CEO had also got involved later in the situation and expressed confidence in her ways of dealing with it. Thus, according to this viewpoint, she was not to be held morally responsible for the losses.

6. What would you have done if you were in Zoe Cruz's situation when the losses started mounting?

This is up to the reader.

7. How would you explain Zoe Cruz's actions in terms of attribution and ethics?

A criticism of Zoe Cruz was in her response to "who was responsible for the mortgage related actions?" Reportedly her response was to identify certain people in the firm, other than herself. An employee who does so might be said to commit attribution errors of different kinds. One is a "fundamental attribution error", which is to focus on internal causes when dealing with other people's behavior. Another is "selfserving bias", which is to make internal attribution for success, but external for failure, where a person takes credit for success but moves the responsibility to others in case of failure. Indeed, these biases are found most commonly in the U.S.

Ethics is the study of moral values and behavior and ethical behavior is acing ways that are consistent with both personal values and organizational or social ones (Nelson and Quick, 2008). A great challenge for managers is when their personal ideal of ethical behavior clashes with the day-to-day realities of the organization. Ethical values can be instrumental or terminal. Surveys such as the Rokeach Value Survey have identified the top ranked instrument values as: honesty, ambition, responsibility, forgiving nature and courage. The top ranked terminal values were: world peace, family security, freedom, happiness, self- 
respect and wisdom. Employees have the choice of what values they identify with and use to guide their actions.

A common ethical approach is following the adage "the ends justify the means". If the reports are accurate, Ms. Cruz appears to have believed in this and thus followed the teleological approach (Chandan and Lakshminarayanan, 2007). In terms of instrumental values, we can infer that Ms. Cruz exhibited ambition and courage. This is supported by the actions she took in the firm and the kinds of jobs she did. They were challenging in many dimensions - in terms of taking risks, in dealing with an unfamiliar work place etc. In terms of terminal values, we could say that she showed "firm security" (and loyalty to the firm). This is supported by her being with the same firm for all her career and her reported devotion to her job.

8. Trace the organizational politics at work in the firm that affected Ms. Cruz's career. Do you agree with her approach in dealing with them?

In terms of organizational politics and managing her career progress, Ms. Cruz, like all employees (and especially those ascending to higher levels) had several choices to make:
a. which divisions to work in (easy or tough ones)
b. who to be allies with
c. who to get as a mentor and protector
d. who to get as mentees or supporters
e. how to negotiate and moderate positions of supporting others
f. how to mend fences with those who had been antagonized

Organizational politics is defined as the "use of power and influence in organizations" and political behavior as "(actions) that are not sanctioned by the organization that are taken to influence others and meet personal goals" (Nelson and Quick, 2008, p. 356-359).

In Morgan Stanley, as in all other organizations, politics was unavoidable. As individuals go up the organization, survival and success is dependent on political skills as much as ability.

Political potential of individuals has been linked to certain traits (Nelson and Quick, 2008, p. 366). These are: being: articulate, sensitive, socially adept, competent, popular, extraverted, self-confident, aggressive, ambitious, devious, intelligent, logical and an "organization" person. Ms. Cruz exhibited many of these traits and that doubtless helped in her rise to the top.

One criticism leveled at Ms. Cruz was that she was not adept at playing politics and tried to bulldoze her way instead of using finesse. A unique type of organizational politics that affected Ms. Cruz's career was the revolt by certain senior executives and board members against CEO Purcell. This was well-reported at that time. Ms. Cruz had initially been under the political protection of John Mack who had been at the firm but had left it during that time. Ms. Cruz reported to Vikram Pandit, who was reportedly critical of her performance. Mr. Pandit was one of the leaders in the revolt against CEO Purcell. When Ms. Cruz made the fateful decision to support CEO Purcell, it might have sealed her fate with Mr. Pandit and his supporters. Although Mr. Pandit left soon after and later headed Citigroup, the lingering effects of that series of events may not have been forgotten. An organizational employee, and particularly executives, often has the choice of who to align with and this can make or break a career.

9. Could, and should, Zoe Cruz have done anything to salvage the situation of the losses?

One option for any employee is to offer to take responsibility and step down, which Zoe Cruz could have done. Another view is that at higher levels, delegation has serious implications and there were others that were held as more directly responsible for the losses. This method has a risk of backfiring where the person who does not take responsibility (however unfair they might perceive it to be) is not held in great esteem. As mentioned earlier, Ms. Cruz's actions could be interpreted as attribution errors. Based on practical evidence, candidates who respond to questions about past failures with internal attribution are more 
successful than those who respond with external attributions (Silvester, 1997). On that basis, Ms. Cruz would have been well advised to take responsibility, or even blame, for what happened. Another choice for an employee in the position where the situation is spiraling out of control and where the subordinates are purportedly ignoring directives, is to push more forcefully for the directives to be followed, even going to higher levels, if need be. The risk in that case is a perception of ineffectiveness and inability to control subordinates, but that has to be balanced against the risk of the negative fallouts from the situation.

\section{EPILOGUE}

Morgan Stanley was affected by the turmoil on Wall Street in that came to the fore in 2007-2008. Along with several other firms in the industry, the company received financial assistance in the form of TARP from the Federal government in 2008. The company reported that this money was paid back in 2009 (Morgan Stanley 2009). The Federal government indicated that there would be stricter industry controls and regulations to ensure that similar conditions to what happened in 2008 would not be repeated.

There was little news of Zoe Cruz for some months; however, it was reported in Wall Street Journal in October 2009 that Ms. Cruz was planning to launch a hedge-fund of her own and start her own business to that end (Luccheti and Strasburg 2009). Since then there have been reports that the hedge fund has been struggling and even lost key personnel (Comstock 2011).

Wall Street continued to have dearth of high ranking women top executives. However, women did lead several large, non-financial services firms such as eBay, Hewlett-Packard and Xerox. The numbers of women in the "pipeline", in high level executive positions, had also shown an overall increase (Hymowitz 2009). This could be interpreted to indicate to an increase in women CEO numbers in the future, although probably not in the financial services firms.

\section{REFERENCES}

1. Chandan, J. S. and Lakshminarayanan, S. (2007). Principles of Management. Houghton Mifflin.

2. Comstock, C. (2011, March 17). Zoe Cruz's Name Gets Mocked in the NYPost. Retrieved June 28, 2011 from http://www.businessinsider.com/zoe-cruzs-hedge-fund-richard-bani-leaving-2011-3.

3. Hymowitz, C. (2007, November 19). The 50 Women to Watch 2007. The Wall Street Journal. Retrieved on December 10, 2009 from http://online.wsj.com/article/SB119524435246896051.html?mod=2-1332-1.

4. Lucchetti, A. and Strasburg, J. (2009, October 9). ‘Cruz Missile’ Returns With a Hedge Fund. The Wall Street Journal. Retrieved December 10, 2009 from http://online.wsj.com/article/SB125504628364874829.html .

5. Morgan Stanley Statement on TARP Repayment and Regulatory Reforms, Retrieved from http://www.morganstanley.com/about/press/articles/b7cf5f77-5b47-11de-96f6-3f25a44c9933.html, December 10, 2009.

6. Nelson, D. L. and Quick, J. C. (2008). Organizational Behavior: Foundation, Realities and Challenges. Thomson South Western Publishers.

7. Silvester, J. (1997). Spoken Attributions and Candidate Success in Graduate Recruitment Process. Journal of Occupational and Organizational Psychology, 70, 61-71.

8. Yukl, G. (2006). Leadership in Organizations (6 ${ }^{\text {th }}$ Edition). Pearson Education, Printed in India. 


\section{NOTES}

